\title{
FEASIBILITY OF PREPARING NESTING BOX AND LURING LARGE SOLITARY CARPENTER BEE, XYLOCOPA VALGA
}

\author{
Michał Schulz ${ }^{1}$ \\ Radosław Ścibior ${ }^{2}$ \\ Kamil Badurowicz ${ }^{1}$ \\ Aleksandra Łoś 1 \\ Milena Bajda ${ }^{1}$ \\ Justyna Tyszczuk ${ }^{1}$ \\ Patrycja Skowronek ${ }^{1}$ \\ Bartłomiej Piotrowski ${ }^{1}$ \\ Aneta J. Strachecka ${ }^{1 *}$ \\ 1 University of Life Sciences In Lublin, Faculty of Biology, Animal Sciences and \\ Bioeconomy, Institute of Biological Basis of Animal Production, Akademicka 13, \\ 20-950 Lublin, Poland \\ ¿University of Life Sciences In Lublin, Faculty of Biology, Animal Sciences and \\ Bioeconomy, Department of Zoology, Animal Ecology and Wildlife Management, \\ Akademicka 13, 20-950 Lublin, Poland \\ *corresponding author: aneta.strachecka@up.lublin.pl \\ Receives: 7 August 2017; accepted: 28 September 2017
}

\section{A b s t r a c t}

Xylocopa valga, commonly called the carpenter bee and the largest bee with metallicviolet hair cover, is extremely rarely observed in Poland. We hypothesize that a stable and possibly long-term population of $X$. valga can be maintained in Poland through the creation of suitable nesting conditions. $X$. valga has been observed since the spring of 2014 in Wisznice (south-eastern Poland). A nesting box made out of 25 wooden blocks with drilled holes was hung about 2.5 meters above the ground. $X$. valga were interested in the blocks made of willow wood but did not nest in the beech, alder and pine. The carpenter bees chose holes made with drill bits of 10, 15, $20 \mathrm{~mm}$ in diameter and a length of 10,15 and $20 \mathrm{~cm}$. $X$. valga flying in the same direction most often visited the flora taxa: Aquilegia vulgaris, Ballota nigra, Consolida ajacis, Delphinium consolida, Deutzia scabra, Catalpa spp., Wisteria spp., Robinia ambigua, Stachys spp. and Trifolium pretense. $X$. valga is a solitary bee, but unlike most other solitary bees it demonstrates aspects of social behavior. It was observed to display cohabitative behavior involving the use of a single hole by more than one female. The females showed aggressive defensive behavior and if approached too closely started buzzing loudly. The information obtained during the long-term observation shows that $X$. valga can be maintained in partly artificial conditions to increase and stabilize the bee population.

Keywords: carpenter bee, endangered species, nesting box, solitary bee, Xylocopa valga

\section{INTRODUCTION}

Xylocopa valga (Gerstaecker, 1872), rarely recorded in Poland, is the largest and most spectacular bee with characteristic metallic-violet hair cover (Fig. 1A) (Michener, 2000; Huflejt \& Gutowski, 2016). The species has a wide range of distribution over almost all of Europe, North Africa and Asia (from Belgium and France to Mongolia and China) (Özbek, 2013). The IUCN states that the species is extinct in Latvia and Lithuania, critically endangered in Poland, Germany and Slovenia, vulnerable in Moldova, Switzerland and Ukraine, but is considered to have a stable population in France (Terzo \& Nieto, 2013). Poland forms the northern border of occurrence for $X$. valga, although it has been observed in only a dozen or so south-eastern and eastern locations in the country over the last 150 years (Banaszak, 2004; Banaszak \& 


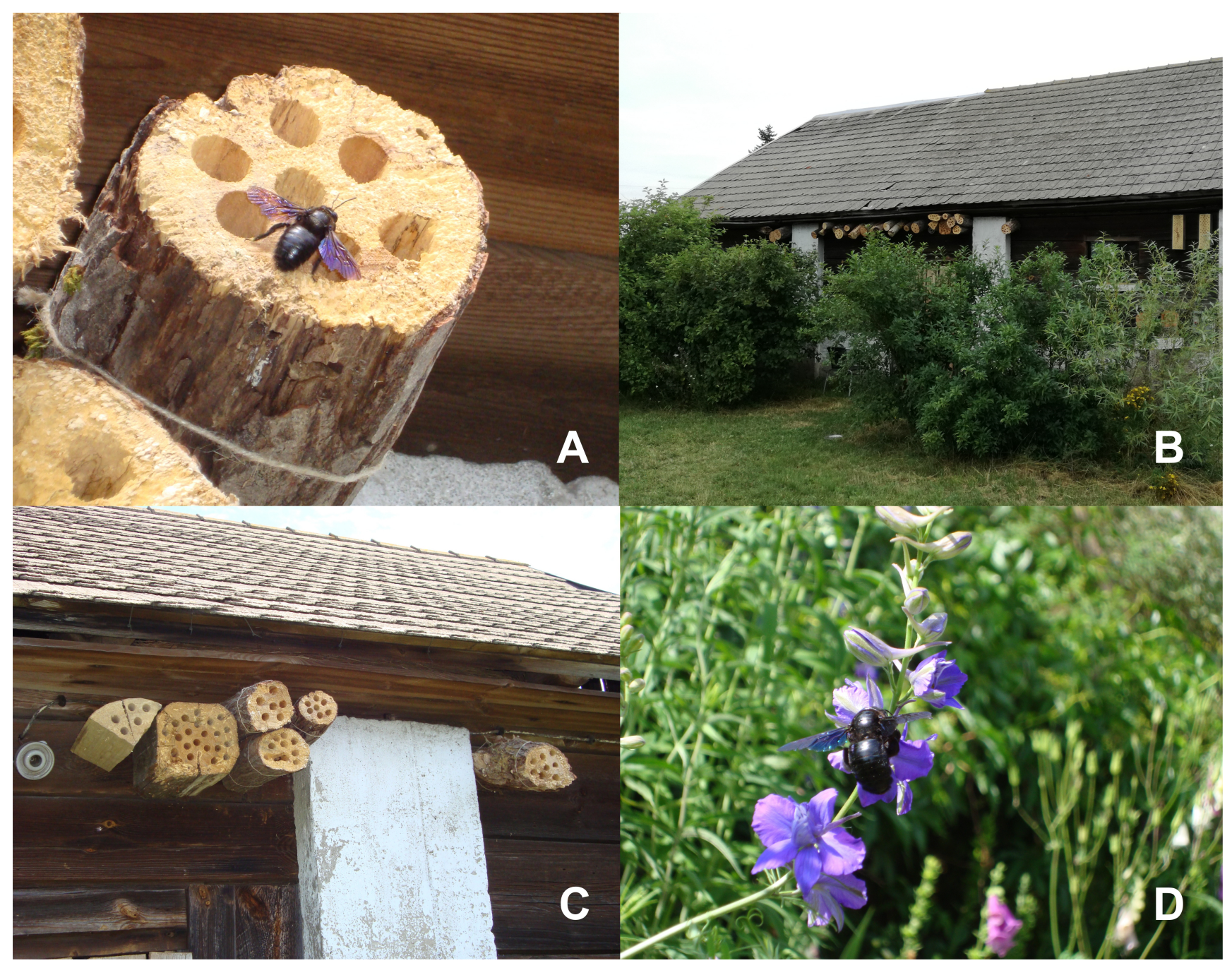

Fig. 1. A. Xylocopa valga on a willow block, B. Nesting box, C. Several unpainted wooden blocks from the prepared nesting box, D. A Xylocopa valga bee feeding on a Consolida ajacis flower.

Piotrowski, 2005; Huflejt \& Gutowski, 2016). $X$. valga lives in continental climate zones with natural woody, shrubby and temperate grassland vegetation habitats (BanaszakCibicka, 2006; Terzo \& Nieto, 2013). In Romania, Slovakia and Croatia it is called "gypsy buzzers" or "buzzers" and formerly was connected with the recently discovered folk tradition of black-bee honey stomach consumption (Ulicsni, Svanberg, \& Molnár, 2016). The drop in the population in western Europe and permanent withdrawal to the south has been linked to the declining numbers of wooden buildings, fences and telegraph poles, and the removal of shelter belts, xerophytic woodlands, steppe slopes, old, rotten trees, all which had created favorable nesting conditions for this bee (Kułak \& Chmielewski, 2010; Terzo \& Nieto, 2013).

This solitary carpenter bee species occurs from early spring to late autumn. The females excavate galleries in wood to create 10-12 brood chambers with the partitions being made of wood dust. Each compartment contains a portion of pollen on which the female deposits an egg. After the nest is complete the mother remains inside the entrance to protect and control the offspring. Young males and females spend the winter in the wood tunnels (Terzo \& Nieto, 2013). Bernardino \& Gaglianone (2013) precisely compared and described the nesting behavior as well as the management of the related species $X$. ordinaria and $X$. frontalis. Therefore, we hypothesized that it is also possible to maintain a stable and probably long-term population of $X$. valga in Poland by creating suitable nesting conditions. The long-run aim is to restitute this unique bee and increase the biodiversity of pollinating insects in Poland. 


\section{MATERIAL, METHODS, RESULTS AND DISCUSSION}

In the spring of 2014 we placed a suitable nesting box, according to the method of Bernardino and Gaglianone (2013), in the village of Wisznice (south-eastern Poland, UTM FC53), to lure the $X$. valga where it had been reported, and since then we have observed the natural appearance of this species, the nesting material, the available plants and individual behavior. The nesting box hung about 2.5 meters above the ground and was made of 25 wooden blocks with drilled holes (Fig. 1B). We used willow (Salix caprea), beech (Fagus sylvatica), alder (Alnus glutinosa) and pine (Pinus sylvestris) as nesting material. Holes were made in each wooden block in every combination with a drill bit of 10, 15, 20 $\mathrm{mm}$ diameter and a length of 10,15 and $20 \mathrm{~cm}$. No preservative substance was used to coat the wood (Fig. 1C). The bees were only interested in blocks made of willow wood regardless of hole diameter or length.

The village of Wisznice and adjacent areas were overgrown with easily heated psammophilous flora which served as a substitute for the Mediterranean habitat. We noticed that the bees most often visited the following flora taxa: Aquilegia vulgaris, Ballota nigra, Consolida ajacis (Fig. 1D), Delphinium consolida, Deutzia scabra, Catalpa spp., Wisteria spp., Robinia ambigua, Stachys spp. and Trifolium pretense. One of the most commonly visited plants in the Mediterranean climate was Lavandula $x$ intermedia (Ruszkowski, Biliński, \& Kosior, 1997; Terzo, Iserbyt, \& Rasmont, 2007) but in this study $X$. valga bees were observed to ignore this plant species even though it grew at the place of nesting. Additionally, we observed bees flying outside the nesting area always along the same route.

$X$. valga is a solitary bee, but unlike most other solitary bees it demonstrates aspects of social behavior (Prager, 2014). We managed to observe cohabitative behavior in which more than one female used a single hole. Additionally the observed females showed aggressive defensive behavior. If approached too closely, they started buzzing loudly and, when photographed, attacked the camera.

The warmer temperatures in recent years has definitely affected $X$. valga distribution and may have shifted the range into Poland (Kozuchowski \& Degirmendzic, 2005). Furthermore current old farmland abandonment and escalation of neglected gardens (Estel et al., 2015) may multiply potential nesting places for this species. Huflejt \& Gutowski (2016) used historical and current sources to create a precise compilation of plant species visited by $X$. valga. Our results showed that other non-indigenous plant species could also be visited by this bee, we concluded that it flexibly adjusts to the food base and adapts to different environments.

\section{CONCLUSIONS}

The information obtained during the four-years study of this rare species demonstrates that they can be maintained in partly artificial conditions. However, recent reports have suggested that this wild species could be a potential reservoir of widespread and crosstaxonomic infective diseases such as the Black queen cell virus (Radzevičiūtè et al., 2017) or deformed wing virus (DWV) (Lucia et al., 2014). We believe that artificial nests could be built to increase and stabilize the population of $X$. valga. More importantly, there is a need to screen solitary bee populations to prevent the spread of diseases and parasites and eliminate the reasons for the decrease in the number of pollinating insects in Europe.

\section{AUTHORSHIP}

MS (20\%) came up with the idea of the publication, gathered and reviewed the literature, took care of analyses' results and the first draft. RŚ (15\%) helped gather the material and prepare the first draft of the publication. KB (15\%) performed an initial review of the literature, came up with the idea of the experiment, conducted it and made all observations. At (15\%) improved and edited the publication from draft to the final version. MB (5\%), JT (5\%), PS (5\%), BP (5\%) edited the publication. As the 
team leader, AS (15\%) supervised all stages of the work.

All authors accepted the final version of the publication and declared no conflict of interest.

\section{REFERENCES}

Banaszak-Cibicka, W. (2006). Zagrożenia i ochrona prawna wybranych gatunków dziko żyjących pszczół (Hymenoptera: Apoidea: Apiformes). Wiadomości Entomologiczne, Poznań, 25, 17-20.

Banaszak, J. (2004) Xylocopa valga Gerstaecker, 1872. Zadrzechnia czarnoroga. [W:] Głowaciński Z., Nowacki J. (red.): Polska Czerwona Księga Zwierząt, Bezkręgowce. Instytut Ochrony Przyrody PAN, Kraków. 220-221.

Banaszak, J., \& Piotrowski, W. (2005) Dwa bardzo rzadkie gatunki pszczół w Polsce: Xylocopa valga GERSTAECKER i Xylocopa violacea (L.) w Poleskim Parku Narodowym. Wiadomości entomologiczne, Poznań, 24 (2): 77-80.

Bernardino, A. S., \& Gaglianone, M. C. (2013). Comparisons in nesting biology of two sympatric carpenter bee species (Apidae: Xylocopini). Journal of Natural History, 4721-22), 1481-1499. http://dx.doi.org/10.1 080/00222933.2012.763054

Estel, S., Kuemmerle, T., Alcántara, C., Levers, C., Prishchepov, A., Hostert, P. (2015). Mapping farmland abandonment and recultivation across Europe using MODIS NDVI time series. Remote Sensing of Environment, 163, 312-325. http://doi.org/10.1016/j. rse.2015.03.028

Huflejt, T., \& Gutowski, J. M. (2016). Xylocopa valga Gerst. (Hymenoptera: Apidae) in Poland. Forest Research Papers, 774), 341-351. http://doi. org/10.1515/frp-2016-0035

Kozuchowski, K., \& Degirmendzic, J. (2005). Contemporary changes of climate in Poland: trends and variation in thermal and solar conditions related to plant vegetation. Polish Journal of Ecology, 53(3), 283-297.

Kułak, A., \& Chmielewski, T. J. (2010). Changes in the physiognomy of the landscape of the West Polesie from the middle of the 19th century till the beginning of the 21st century. In The Future of Hydrogenic Landscapes in European Biosphere Reserves. (pp. 29-40) Lublin: University of Life Sciences.

Lucia, M., Reynaldi, F. J., Sguazza, G. H., \& Abrahamovich, A. H. (2014). First detection of deformed wing virus in Xylocopa augusti larvae (Hymenoptera: Apidae) in Argentina. Journal of Apicultural Research, 53(4), 466-468. http://dx.doi.org/10.3896/ IBRA.1.53.4.11

Michener, C. D. (2000). The bees of the world (Vol. 1). JHU Press.

Özbek, H. (2013). New data on large Carpenter-bees of Turkey with considerations about their importance as pollinators. Journal of the Entomological Research Society, 15(1), 79-89.

Prager, S. M. (2014). Comparison of social and solitary nesting carpenter bees in sympatry reveals no advantage to social nesting. Biological journal of the Linnean Society, 113(4), 998-1010. http://doi. огg/10.1111/bij.12395

Radzevičiūtè, R., Theodorou, P., Husemann, M., Japoshvili, G., Kirkitadze, G., Zhusupbaeva, A., Paxton, R. J. (2017). Replication of honey bee-associated RNA viruses across multiple bee species in apple orchards of Georgia, Germany and Kyrgyzstan. Journal of Invertebrate Pathology, 146, 14-23.http://doi. org/10.1016/j.jip.2017.04.002

Ruszkowski, A., Biliński, M. \& Kosior, A. (1997) Rośliny pokarmowe i znaczenie gospodarcze mniej znanych gatunków pszczół porobnicowatych (Hymenoptera, Apoidea, Anthophoridae). W: Postępy apidologii w Polsce. T. Cierzniak (red.). WSP, Bydgoszcz: 239-258.

Terzo, M., Iserbyt, S., \& Rasmont, P. (2007). Révision des Xylocopinae (Hymenoptera: Apidae) de France et de Belgique. Annales de la Société Entomologique de France, 43(4), 445-491.

Terzo, M. \& Nieto, A. (2013) Xylocopa valga. The IUCN Red List of Threatened Species 
2013: e.T13325229A13325391. Downloaded on 31 July 2017. http://www.iucnredlist.org/details/13325229/1

Ulicsni, V., Svanberg, l., \& Molnár, Z. (2016). Folk knowledge of invertebrates in Central Europe-folk taxonomy, nomenclature, medicinal and other uses, folklore, and nature conservation. Journal of Ethnobiology and Ethnomedicine, 12(1), 47. http://doi. org/10.1186/s13002-016-0118-7 